\title{
Instructing the Indians at Botany Bay
}

\author{
RC Petersen
}

The first books brought to Australia included twelve copies of a book listed by both Bonwick in 1898 and Macintosh in 1978 as Wilson's Instructions for the Indians. ${ }^{1}$ These twelve copies were in the store of over four thousand volumes brought out on the First Fleet by Richard Johnson (1753-1827), the clergyman attached to the expedition as chaplain for the convicts and their guards. The books, published by the Society for Promoting Christian Knowledge, had been given to Johnson by the Society for the Propagation of the Gospel in Foreign Parts, for him to use in his pastoral work in the penal colony that was to be established. ${ }^{2}$ Johnson brought out some fifty titles in various quantities. There were 200 copies of the Church of England catechism, 200 copies of Christian Soldier, 100 Exhortations to Chastity, six copies of the Great Importance of a Religious Life Considered by William Melmoth, and one copy of Osterwald's Arguments. There were 500 copies of Stonehouse's Administrations printed on a big sheet of paper, and 100 copies of it stitched into booklets. ${ }^{3}$ The Society for Promoting Christian Knowledge also gave Johnson some schoolbooks with the expectation that a school would be opened at Botany Bay. The Child's First Book Part One was supplied in 200 copies and the work by Henry Dixon, The English Instructor, Etc., Or, the Art of Spelling Improved in 100 copies, but only one copy was included of Talbot's Christian Schoolmaster, that is James Talbot's 1707 work, The Christian Schoolmaster: or the duty of those who are employ'd in the publick instruction of children, especially in charity schools. Maybe Johnson himself owned some other books on education and pedagogy, and maybe their lessons were utilised when Australia's first school opened in 1789 or when Johnson set up schools from 1792 on. ${ }^{4}$ We do not know this, it seems. But the most numerous items in the cargo were, as would be expected, Bibles and separately published parts of the Bible like the Psalms. Some years later, more boxes of books were sent out to Botany Bay by the Society for the Propagation of the Gospel. 5

It would be interesting to investigate the contents of all of them, of all these first European 'cultural items' brought to the continent, but here only Wilson's book is

1. They are listed in Bonwick 1898: 55-7 and Macintosh 1978: Appendix 2, 105-6.

2. They did the same in Georgia, fifty years earlier, and including some of the same books. See list in Church 1932: 236.

3. Wood (1926: 243) also refers to the books.

4. Cleverley 1971: ch. 6 .

5. Johnson, letter of 6/12/94 (Mackaness $1954 \mathrm{vol} \mathrm{II:} \mathrm{10);} \mathrm{letter} \mathrm{of} \mathrm{31/8/1798} \mathrm{(Mackaness} 1954$ vol II: 28$)$. 
treated. It must be remembered that Johnson and the Society for Promoting Christian Knowledge understood that the settlers were coming to an inhabited land. It was not only the convicts and their guards with whom Johnson expected to deal, it was also the indigenous people of Botany Bay, the Aborigines. How should these be approached? The twelve copies of Wilson's Instructions for the Indians, a product of the American experience, were the only ones in Johnson's Iuggage patently for use with the Aborigines. In his history of Aborigines encountering Christianity, Harris remarks that the Society for the Propagation of the Gospel in Foreign Parts sent Johnson to Botany Bay, but that 'this did not inspire them to any early action on behalf of the Aboriginal people'. ${ }^{6}$ Their inclusion of Bishop Wilson's book in his luggage seems to show, on the contrary, that they did. Of course it rested with Johnson how he would use Wilson's book.

The land was inhabited by its natives; and the English had a long experience of natives. The eyes which looked upon the natives of Australia were not.innocent eyes. Precedents were established: by 1788 the English had been dealing with the indigenous people of the Americas for over two hundred years. It is almost certain that the English coming to Australia brought with them attitudes to its natives formed or at Ieast influenced by the English experience of the American Indians. ${ }^{7}$ Indeed, in the first texts, they are often spoken of as Indians. ${ }^{8}$ La Perrouse in 1788 referred to them as 'the Indians of New Holland'. As late as 1819 Barron Field called them Indians. The Americas had been discovered three centuries already, and the First Fleet called in at Rio de Janeiro on its way out. The governor, Arthur Phillip, had been for years in Portuguese naval service in Brazil, at Rio where Indians and Blacks from Africa went about the streets. ${ }^{9}$

The Instruction for the Indians was not written in the American colonies, however. The book, whose title was finally The Knowledge and Practice of Christianity Made Easy to the Meanest Capacities; or, An Essay Towards an Instruction for the Indians [etc.], was written in England by Thomas Wilson and first published in 1740.

It was a catechism, that is a course of lessons in the form of questions and answers, sustained over a hundred and fifty pages in Wilson's Works scrupulously edited by John Keble for the Library of Anglo-Catholic Theology in the 1860s and double that in the duodecimo edition of 1781 , which presumably was the one Johnson used. ${ }^{10}$ The questions were asked by an Indian and answered by a Missionary. In nine dialogues the interlocutors proceed to explicate systematically the reasons why human beings should desire Christian baptism. Then dialogues follow on the Nicean Creed and its implications, on the Ten Commandments, on duties to God and neighbours, on prayer, and on the Lord's Supper (or Holy Communion). The twentieth dialogue is on 'the delusion, the danger, and the mischief, of being Christians without Christianity', and it is here that the Missionary asks the Indian to abandon pagan practices, saying: 'And

6. Harris 1990: 40-1.

7. Berkhofer (1988) has a succinct and temperate account of European visions. The sections on the Indians in FG Wood (1990) are, like the rest of his book, a little overwrought.

8. Tench 1961, passim. Here I should note that I use 'Indians', and not terms like 'Native Americans' which have been fashionable lately, to refer to the indigenous inhabitants of the Americas. I believe I am supported in this by Francis (1992), and especially Ward Churchill (1995).

9. Frost 1987: ch. 4.

10. A copy of the 1781 edition is preserved in the library of Moore College, Sydney. There was an edition in 1787 but Johnson was given the books in late 1786 . 
first, Consider whether there are any ways of life, or customs, which at present you are fond of, which you will not utterly forsake, when you shall be convinced that they are forbidden by God, or displeasing to him.' To which the Indian replies: 'I know of none which I will not forsake in order to please God.'

The author of the book, Bishop Thomas Wilson (1663-1755), seems to have been a kindly man, with a saintly concern for the welfare of his flock. Educated at Trinity College Dublin, he was appointed to the see of Sodor and Man at the age of 34 and held it for fifty-eight years (1697-1755), living on the Isle of Man among the Manx people, learning the Manx language (which is or was a Celtic language related to Irish), translating parts of the Bible into Manx, even writing some of his own works in Manx. ${ }^{11} \mathrm{He}$ was so beloved by the rough and simple Manx that the good bishop believed he could also reach American Indians and other savages.

He was asked to write a catechism for the Creek Indians of Georgia by James Oglethorpe (1696-1785), administrator of Georgia and founder of Savannah. ${ }^{12}$ Oglethorpe had the welfare of the Indians at heart; and while admiring their virtues wished to make them Christians, any sort of Christian (except Catholic and perhaps Wesleyan). He returned to England from Georgia in 1743 bringing with him some specimens of Indian humanity : Tomochichi the mico (or chief) of the Yamacraw Creeks, his wife Scenawki or Sarauki, his fifteen year old great-nephew called Tonahowi or Tooanaliomo, and half a dozen retainers. ${ }^{13}$ The Creeks were paraded around England (though not so far as the Isle of Man) and immortalised in paintings dressed in wolf-skins and clutching eagles. They presented a deerskin and eagle feathers to King George II, and asked 'for the good of the children of our Nation that they may be instructed in the knowledge of the English'. ${ }^{14}$ When Oglethorpe and Wilson met in London it seems that the Indians were elsewhere so that Wilson never met them, he only heard about them from Oglethorpe and from his own son. It was his son who saw them at Kensington Palace on 1 August 1734, noting that 'they behaved with a becoming Gravity, not too much admiring the furniture or the Dress of the Court tho' very splendid', true Stoics. ${ }^{15}$. But pressed by his son and Oglethorpe, Bishop Wilson agreed to write a catechism for Tomochichi and the Creeks, or at least for generic Indians.

The Creeks were an agricultural people living in semi-permanent villages and cultivating corn on the rich soils of what are now Georgia and Alabama. ${ }^{16}$ There are still some Creeks but their ethnic homelands were long since lost to them, and after a forced march of thousands of kilometers in the 1830s most surviving Creeks settled in Indian Territory, a fake homeland which in turn was lost to them in 1907 when it became Oklahoma. ${ }^{17}$ They had chiefs and war chiefs, but these positions seem not to have been hereditary. In fact, the Creeks were matrilineal. Their life was structured by the seasons and the farming tasks of each, and culminated in a Festival of the Green Corn around

\footnotetext{
11. See Keble 1863. There is an entry in DNB. Wilson is considered the initiator of Manx literature.

12. See Church (1932) and Corkran (1967). There is an entry in DNB.

13. Ibid. There are pictures of them in Swanton 1946, Plates 29 and 30.

14. Linnell 1964: 117.

15. Ibid.

16. Adair nd; Burt and Ferguson 1973; Swanton 1922 and 1946.

17. Burt and Ferguson 1973: chs 15-17.
} 
the end of July, when after being extinguished the hearths were relit for a year. ${ }^{18}$ Before battle the braves drank the concoction of a kind of holly, a black liquid which immediately purged them. The men were fine athletes; they played lacrosse; both sexes danced. Swanton's books lovingly collect all the facts about this people. ${ }^{19}$

Oglethorpe's protegees, however, were not representative of the Creek nation. Tomochichi seems to have been the self-appointed leader of a tiny fraction of the nation, calling themselves the Yamacraw, that had fallen out with the rest and, finding themselves at the site of Savannah, had attached themselves to the powerful white men. They were almost exactly the American equivalent of the Aboriginal 'kings' in Australia, honoured and used by outsiders who had not the faintest understanding of indigenous politics. ${ }^{20}$ Well might Oglethorpe consider the Creeks to be a docile and pliable nation, for he was dealing with demoralised people.

Wilson seems to have known nothing of all this. The Indian who speaks in his catechism is a figment of the European imagination, nourished probably in equal measure by classical literature and reports of modern voyages. He took Oglethorpe's word for the Creeks' possessing almost Roman virtues, as these could be studied in Livy. Oglethorpe even thought that, through the interpreters, he detected an eloquence equal to the ancients; and he went so far as to say, 'I am a red man, an Indian in my heart, that is why I love them'. Their simplicity of life and their austere manly virtues led Wilson in turn to read them as the Cynics and Stoics portrayed by Diogenes Laertius and others. And he presumably took the whole matter of America from books like LA Lahontan's Dialogues Curieux entre l'Auteur et un Sauvage de Bon Sens qui a Voyagé (1703), John Lawson's New Voyage to Carolina (1709), the Jesuit Joseph Lafitau's Moeurs des Sauvages Américains Comparées aux Moeurs des Premiers Temps (1724), and Cadwallader CoIden's History of the Five Indian Nations of Canada (1727). These books typify the pro-Indian literature of the period; and Lafitau was one of the many Europeans raised on Virgil, Tacitus and Lucretius who believed they could draw Classical parallels with Indian cultural practices. ${ }^{21}$ James Adair, who was collecting data on the Creeks in those very years, for his part insisted on viewing them as the Lost Tribes of Israel. The 'Other' is a Rorschach blot. ${ }^{22}$ The Indian of Wilson's dialogue is a 'sauvage de bon sens', philosophical by nature, grave and reasonable, a sensible savage. He is not an especially noble savage, however, savages being human and therefore as liable to sin as the most highly civilised of men. Wilson expatiates upon 'the cruelty, the oppression, the pride, the injustice, the malice, the covetousness, the lewdness, the impurity, murders, drunkenness, and all other sins' which all humans commit. ${ }^{23}$ Just as reason is the great leveller up, so sin is the great leveller down.

It is of course a plausible deduction that, if American savages were deemed reasonable beings, then all humans were reasonable and could be reached by messages

18. Corkran 1967: 34-9.

19. He also edited notes made by JNB Hewitt in 1881-82 from interviews.

20. On these see Tanya Cleary's Poignant regalia and Jakelin Troy's King plates (both 1993).

21. Honour (1975) deals with this theme.

22. Many examples of this literature are surveyed in Sayre (1997); the Indian problematic is well exposed in Todorov (1992).

23. Wilson 1861: 155-6. 
pitched at their reason - and so Wilson deduced. Of the African slaves he said that 'nobody ought to question, but that these people are as capable of receiving religious instruction as any other Gentiles, or even as we ourselves were, when the Gospel was first preached to us'. Here 'we ourselves' are the English, an allusion presumably to non Angli sed angeli. ${ }^{24}$ It was not implausible, then, that the book promised to be useful with the black natives of Australia. Wilson said that 'heathens can reason as well as Christians' ${ }^{25}$ All these people had reason and all were sinners, regardless of their race. 'Human nature, as it is now corrupt, is the same in all men.' ${ }^{26}$ It is a question, however, whether the Indian in Wilson's dialogue would have shown himself so rational had he been envisaged as female: the noble savage, and even the antique pagan, was almost always taken to be a man.

Wilson heard from Oglethorpe about the Indians of Georgia, 'who, as he assured us, are a tractable people, and more capable of being civilized, and of receiving the truths of religion, than we are generally made to believe' ${ }^{27}$ All that was needed, really, was to remove some hindrances, and take proper measures to awaken in them a sense of their true interest, and make them realise their unhappy condition so long as they remained pagan. In his book, Wilson set out to emulate Jesus, 'to follow the example of our Great Master, - by giving instructions suitable to the present necessity and strength of such as were to receive them' ${ }^{28}$ This is a doctrine of economy. The instructions built upon what 'plain and unlearned people'... 'know and feel within themselves, - upon the corruption of human nature, - their proneness to evil, - the fears that attend such a sad state, - and upon the experience of their own utter inability to deliver themselves out of this state of bondage; - arguments which every thoughtful man, though never so unlearned, if awakened, feels the force of ${ }^{\prime 29}$ There is no Indian decor in the book even in the section on the Ten Commandments - where familiar examples were appropriate. Wilson writes of servants who disobey their masters, and of rum and gin as ruining 'many thousands of the lower part of mankind'.$^{30}$ Idolators were bad. As well as maintaining a sacred fire in a circular temple tended by braves, the Creeks had idols. However, when the Missionary says that 'You must know then, through the suggestions of the devil, most nations have been led into a vile custom of representing and worshipping God by images ${ }^{31}$, the wording does not point particularly to Creeks or even Indians.

Wilson populated his world with good spirits and evil spirits, and to frighten the Indian from evil spirits used the examples of Noah's flood and the destruction of Sodom and Gomorrah by fire out of the sky. The Indian says, 'These indeed are reasonable proofs of the power which EVIL SPIRITS have over wicked men, and of the great danger we are in of being ruined by $\mathrm{it}^{\prime} .{ }^{32}$ The very first prayer in the book, apotropaic,

24. Wilson 1861: 142.

25. Wilson 1861: 140 .

26. Wilson 1861: 289.

27. Wilson 1861: 135.

28. Wilson 1861: 136.

29. Wilson 1861: 137.

30. Wilson 1861: 243.

31. Wilson 1861: 235.

32. Wilson 1861: 158. 
names Satan; later Wilson writes of 'the evil spirit, i.e., the DEVIL, who is the great tempter of mankind to all evil' ${ }^{33}$ Angels were mentioned. It was a world in which the grossest superstitions could be called reasonable, and certainly one in which uninstructed Christians were as burdened with pagan residues as the various natives to whom they claimed to be superior. Nevertheless, Wilson assured the Indians that 'these things are true, and will at last be found to be so, whether men believe them or not. And if any man is lost forever, for want of giving credit to them, or for not considering them, it will signify little whether he was called a Christian or a Heathen.' 34

After the Indian had listened to the Missionary, he would be allowed to read the Gospels: 'I mean FOUR SMALL TREATISES, in which the life and actions of our Saviour are written for the benefit of all succeeding Christians; and, when it shall be your happiness to read them, you will find there abundant matter and reason for the perpetual remembrance of Jesus Christ ${ }^{35}$. First the oral Gospel, then the written; and, with that, the schoolmaster.

Although Wilson submitted the manuscript to Isaac Watts for his approval, to make sure Dissenters would also use his book, he did not allow his teaching to become too Protestant. In the tenth dialogue, for example, the Indian is told that there are two sacraments : baptism and commurion, which is against the seven sacraments of Catholics and the Orthodox; and that baptism may be administered to infants and adults, which is against all kinds of Baptists. The whole second half of the book faithfully interprets the Church of England catechism, which Wilson had earlier rendered into Manx.

This Instruction for the Indians was republished regularly until 1848. It reached its thirteenth edition in 1781 and its fourteenth edition in 1787; these presumably furnishing the copies brought to Australia. It was published in French at Geneva in 1744, in Italian by 1757, and in Welsh in 1774; decades later it was translated into Manx but this version was never printed. ${ }^{36}$ What its influence may have been is incalculable. It was distributed among the African slaves on American plantations, or at least distributed among the slave-holders for use with the Blacks. And as early as August 1741, 'a great many thousand of the last edition [had been] sent all over our plantations in the West Indies', being warmly received in Jamaica ${ }^{37}$; while by 1745 it was being used at William and Mary College in Virginia with black, Indian and white students. As to its influence as a literary work, it may be that Voltaire, who was in England in 1726-29 and kept up an interest in things English, was using Wilson's format twenty years later to promote deism in his Entretiens d'un sauvage et d'un bachelier of 1761, and the Catéchisme de l'honnête homme ou Dialogue entre un caloyer et un homme de bien two years later. His subversive catechisms in the Dictionnaire Philosophique of 1764, especially the 'Catechisme chinois', may echo the Instruction for the Indians. ${ }^{38}$ But a confident account of its reception and Fortleben would need a full study.

\footnotetext{
33. Wilson $1861: 267$.

34. Wilson 1861: 231 .

35. Wilson 1861: 274.

36. Keble 1863: 921; British Library Catalog. Berkhofer is silent on Wilson. The only writer I have seen mention Wilson in the Indian context is Beaver 1966: 24.

37. Keble 1863: 918-9.

38. Most of these are printed in Voltaire 1961.
} 
This then was the book of which Johnson brought twelve copies to Botany Bay. If the Indians whom Johnson intended to convert by it, that is if the Aborigines around Sydney Harbour, the Cadigal, the Birranbirragal, the Gorualgal and the Borogegal peoples, with their more distant peers, could have learned English very well, then by reasoning they might have admitted the pre-eminence of the Semitic sky god. They may have had a sky god of their own, Byamee or Baiami, though there is some doubt as to its pre-eminence; but even with a mastery of English there was no way they (or anyone else) could have been led by reason to understanding the triune god of the Christians and the tenets of the Church of England. These are mysteries beyond human understanding ... particularly the tenets of the Church of England.

It is not clear whether Johnson ever used Bishop Wilson's catechism at Botany Bay. We have evidence that Johnson was kindly disposed towards the real indigenes whom he found around him. In May 1788 he said that 'from what I have seen \& heard they are very harmless \& inoffensive'. ${ }^{39} \mathrm{He}$ and Mary Johnson undertook to be charitable to them. In the smallpox epidemic children were orphaned. A boy, Nanbaree, was taken into the care of John White, the Surgeon-General; and a girl, Boorong or Abaroo, was taken into the Johnson household ${ }^{40}$. Thus began the practice of removing Aboriginal children from their parents and relatives. Eleven months later, Johnson reported :

Have taken some pains with Abaroo (about 15 years old) to instruct her in reading, \& have no reason to complain of her improvement. She can likewise begin to speak a little English \& is useful in several things about our little Hutt. Have taught her the Lord's Prayer \&c., and as she comes better to understand me, endeavour to instruct her respecting a Supreme Being, \&c. Wish to see these poor heathen brought to the knowledge of Xtianity \& hope in time to see or hear of the dawnings of that time when these shall be given for our Lord's heritage, \& the uttermost parts of the earth for his Possession'. 41

It is possible to construe some of Johnson's words, words like 'instruct her respecting a Supreme Being' and 'brought to the knowledge of Christianity', to mean that he used Bishop Wilson's approach to proselytise Abaroo; but her slight abilities with speaking and reading English must have kept Instructions for the Indians out of her hands. In any case, before her conversion had progressed very far she decamped and took up with a young man of sixteen, Imeerawanyee. A portrait by the so-called Port Jackson Painter, reproduced in McBryde, shows Abaroo decorated in pink for a funeral. ${ }^{42}$ She was seen about the harbour, paddling naked in a canoe; and by then the 39 Articles of the Church of England were probably very far from her mind. Johnson took another girl into his household, but we have no further information about her except that she soon went walkabout too. In 1792 he asked for two missionaries to be sent out specifically to teach the Aborigines but his request went unheeded; and when some London Missionary Society missionaries did turn up in Sydney in 1798 after their failure in Tahiti, they taught only European children, presumably having had enough of savages noble and ignoble. $^{43}$

39. Johnson, letter of 8/5/1788 (Mackaness 1978 vol I: 19).

40. Macintosh 1978: 56-8.

41. Johnson letter of 9/4/1790, Mackaness I, p. 29.

42. McBryde 1989: 9.

43. Cleverley 1971: 64; Bridges 1968. 
This in bare outline is the story of one book that links three continents and three nations. It would be worth looking closely at all the other books which Johnson brought with him, and seeing if there are others which less patently than Wilson's were nonetheless intended for use with the Aborigines. Wilson's book, however, testifies that the first contacts with Australia's native inhabitants carried at least the promise of humane treatment for people who were accepted as being reasonable. Wilson's Missionary told his Indian that God : 'has given you and all men Reason, which is instead of a written law or rule, by which you ought to live, and may in some measure know what is good, and what is evil; what will please, and what will displease, an holy, just, and good God'. ${ }^{4}$ A promising start for Europeans settling alongside the natives; it was a tragedy that this promise was not fulfilled in the decades and the centuries that followed.

\section{References}

Adair, J, nd [1930] in SC Williams (ed.) The history of the American Indians. New York, Promontory Press.

Beaver, RP, 1966. Church, state, and the American Indians. Saint Louis, Concordia Publishing House.

Berkhofer, RF, 1988. 'White conceptions of Indians', in WE Washburn (ed.) History of Indian-white relations. Handbook of North American Indians, vol. 4. Washington, Smithsonian Institution, pp 522-47.

Bonwick, J, 1898. Australia's first preacher: the Rev. Richard Johnson, first chaplain of New South Wales. London, Sampson Low Marston.

Bridges, B, 1968. 'Aboriginal education in eastern Australia (NSW) 1788-1855.' Australian Joumal of Education 12(3): 225-43.

Burt, J and Ferguson, RB, 1973. Indians of the Southeast : then and now. Nashville, Abingdon Press.

Church, LF, 1932. Oglethorpe: a study of philanthropy in England and Georgia. London, Epworth.

Churchill, W, 1995. Since predator came: notes from the struggle for American Indian liberation. Littleton (CO), Aigis Publications.

Cleverley, JF, 1971. The first generation: school and scciety in early Australia. Sydney University Press.

Corkran, DH, 1967. The Creek frontier 1540-1783. Norman, Oklahoma University Press.

Francis, D, 1992. The imaginary Indian: the image of the Indian in Canadian culture. Vancouver, Arsenal Pulp Press.

Frost, A, 1987. Arthur Phillip 1738-1814 : his voyaging. Melbourne, Oxford University Press.

Harris, J, 1990. One blood: 200 years of Aboriginal encounter with Christianity, a story of hope. Sydney, Albatross.

Honour, H, 1975. The New Golden Land: European images of America from the discoveries to the present time. New York, Pantheon Books.

44. Wilson 1861: 155. 
Keble, J, 1863. The life of the Right Reverend Father in God, Thomas Wilson, D.D., Lord Bishop of Sodor and Man. Oxford, Parker.

Lepore, J, 1999. 'Ich bin ein Indian [sic].' Reviews in American History 27(1): 22-7.

Linnell, CLS (ed.), 1964. The diaries of Thomas Wilson, D.D. 1731-37 and 1750: son of Bishop Wilson of Sodor \& Man. London, Society for Promoting Christian Knowledge.

Macintosh, NK, 1978. Richard Johnson Chaplain to the colony of New South Wales: his life and times 1755-1827. Sydney, Library of Australian History.

Mackaness, G (ed.), 1954. Some letters of Rev. Richard Johnson B.A. first chaplain of New South Wales. Sydney, Ford Prs, 2 vols.

McBryde, I, 1989. Guests of the Govemor: Aboriginal residents of the first government house. Sydney, Friends of the First Government House.

Sayre, GM, 1997. Les sauvages Américains: representations of Native Americans in French and English colonial literature. Chapel Hill, North Carolina University Press.

Swanton, JR, 1922. Early history of the Creek Indians and their neighbors. Washington, Bureau of American Ethnology Bulletin 73.

Swanton, JR, 1946. The Indians of the southeastem United States. Washington, Bureau of American Ethnology Bulletin 137.

Tench, W, 1961 (repr.). Sydney's first four years. Sydney, Angus \& Robertson.

Todorov, T, 1992. The conquest of America: the question of the other. New York, Harper Perennial.

Voltaire, 1961. Mélanges (ed. J van den Heuvel). Paris, NRF, 'Bibliothèque de la Pléiade'.

Wilson, T, 1787. The Indian instructed. London, Rivington for Society for Promoting Christian Knowledge, 14th ed.

Wilson, $\mathrm{T}, 1861$. The knowledge and practice of Christianity made easy to the meanest capacities: or, an essay towards an instruction for the Indians, in his Works, Vol. IV (ed. J Keble). Oxford, Parker, 129-297.

Wood, FG, 1990. The arrogance of faith: Christianity and race in America from the colonial era to the twentieth century. New York, Knopf.

Wood, GA, 1922. 'Australia's first preacher: Rev. Richard Johnson.' Australian Christian World 17 Feb: 7; 24 Feb: 7; 3 Mar: 7-8.

Wood, GA, 1926. 'The Reverend Richard Johnson: Australia's first clergyman.' Joumal and Proceedings of the Royal Australian Historical Society 12(5): 237-70. 